\title{
An Empirically Derived Conceptual Framework to Assess Dis-Adoption of Conservation Agriculture: Multiple Drivers and Institutional Deficiencies
}

\author{
Edna L. Chinseu ${ }^{1}$, Lindsay C. Stringer ${ }^{1} \&$ Andrew J. Dougill ${ }^{1}$ \\ ${ }^{1}$ Sustainability Research Institute, School of Earth and Environment, University of Leeds, United Kingdom \\ Correspondence: Edna L. Chinseu, Sustainability Research Institute, School of Earth and Environment, \\ University of Leeds, Leeds LS2 9JT, United Kingdom. E-mail: eeelc@1eeds.ac.uk
}

Received: August 14, 2019

doi:10.5539/jsd.v12n5p48
Accepted: September 16, 2019

Online Published: September 29, 2019

URL: https://doi.org/10.5539/jsd.v12n5p48

\begin{abstract}
Efforts of national governments and international agencies aimed at alleviating hunger and poverty are often undermined by lack of long-term adoption of agricultural innovations. Studies commonly explain farmers' adoption decisions using household general determinants, yet decision-making, particularly for under-resourced smallholder farmers in sub-Saharan Africa, is a complex process. Using the case of conservation agriculture [CA], this article analyses dis-adoption of agricultural technologies by examining multiple domains of Malawi's CA innovation system and how these influence farmer decision-making. It analyses institutional arrangements of CA promoters, national policies and farmers' experiences. From this, we empirically derive a multifaceted dis-adoption drivers' framework to explain CA dis-adoption in smallholder farming systems. Our findings reveal that adverse features in national policies, institutional arrangements, technological attributes and social cultural dimensions all lead to unfavourable experiences of CA for smallholder farmers, which can culminate in dis-adoption. The CA dis-adoption drivers' framework we develop in this study provides a useful troubleshooting tool. It can be used to guide improvements in the design and implementation of project-based interventions seeking long-term adoption of agricultural innovations across sub-Saharan Africa.
\end{abstract}

Keywords: climate smart agriculture, extension, farming systems, innovation systems, land management, Malawi, policy, stakeholder analysis, sustainable intensification

\section{Introduction}

Ending poverty and hunger remain unaccomplished global goals and have become pressing concerns of national governments and international agencies (Food and Agriculture Organisation [FAO], 2017). The challenge remains despite on-going investments in perceived new agricultural innovations aimed at improving agricultural productivity, food security and income. Conservation agriculture [CA] is one such innovation, widely promoted among smallholder farmers to improve agricultural yields, income, reduce cost of production and for building resilience to climate change impacts (FAO, 2018). CA is anchored on three pillars: minimum soil disturbance (no-till or reduced tillage), continuous soil cover (covering the soil with mulch or cover crop) and crop associations in space and time (Findlater, Kandlikar \& Satterfield, 2019). While studies have shown CA success in some areas (Steward et al., 2018; Kassam, Friedrich \& Derpsch, 2019), others have reported contrary findings (Giller, Witter, Corbeels \& Tittonell, 2009; Cheesman, Andersson \& Frossard, 2017). Widespread dis-adoption seems to persist especially among under-resourced smallholder farmers in sub-Saharan Africa (Glover, Sumberg \& Andersson, 2016).

Dis-adoption, also termed 'discontinuance,' is defined by Rogers (2003) as an individual's decision to reject a technology after having adopted it previously. Two types of dis-adoption/discontinuance are specified: replacement discontinuance and; disenchantment discontinuance. Replacement discontinuance occurs when an individual decides to abandon an innovation, replacing it with another; while disenchantment discontinuance is when an individual rejects a technology due to dissatisfaction with its performance (Oladele, 2005). The concept of dis-adoption continues to be largely neglected in research yet the rate of dis-adoption of an innovation is as significant as the rate of its adoption when determining the magnitude of adoption at any given time (Rogers, 2003). Consequently, CA dis-adoption has largely been ignored; rarely debated, particularly among organisations 
promoting the innovation, despite growing evidence of its occurrence (Pedzisa, Rugube, Winter-Nelson, Baylis \& Mazvimavi, 2015; Arslan, McCarthy, Lipper, Asfaw \& Cattaneo, 2014). Limited knowledge of dis-adoption has not only presented a perplexing scenario for CA proponents but has also prompted critical views reported by several authors (e.g. Andersson \& Giller, 2012; Baudron, Andersson, Corbeels \& Giller, 2012; Whitfield et al., 2015). It is important for agricultural researchers, funding agencies, technology practitioners and change agents to have greater understanding of the concept of dis-adoption and how it occurs, so as to inform more efficient and strategic use of resources to address this challenge.

In-depth analysis of dis-adoption mainly requires answers to 'why' and 'how' questions (Nyanga, 2012). Responses to these questions can provide insights into processes and mechanisms that need to improve to sustain adoption of project-based interventions and their impacts more broadly. Literature is growing on analyses of why dis-adoption occurs (see Chinseu, Dougill \& Stringer, 2019; Oladele, 2005; Moser \& Barrett, 2003; Neill \& Lee, 2001), but the question of 'how dis-adoption occurs' is paramount and needs more adequate conceptualisation. Answering the question 'how does dis-adoption occur and how can it be conceptually illustrated?' is the focus of this article. We fill this research gap by identifying and synthesising underlying drivers of dis-adoption among smallholder farmers in three domains, namely national policies, promoters' institutional arrangements and farmers' experiences in rural Malawi, and then using our empirical data to develop a conceptual framework. Secondly, we engage with the framework, to demonstrate multiple pathways of dis-adoption under smallholder conditions. We do this by examining interactions between drivers within and across individual domains, to concisely illustrate the contribution of its various components to the understanding of dis-adoption among smallholder farmers.

\section{Methodological Approach}

\subsection{Theoretical Framework}

This study has situated CA dis-adoption within the agricultural technology adoption body of knowledge and has been informed by Diffusion of Innovation (Rogers, 2003) and Agricultural Innovation System (Spielman \& Birner, 2008) theoretical perspectives. Adoption of an agricultural technology is a product of complex interactions between individual farmers, perceived attributes of the technology, in this case CA, and 'frame conditions' or surrounding contexts such as social-political systems (Ndah et al., 2012). The selected theoretical frameworks are suitable for this study as their combination covers all relevant aspects: the Diffusion of Innovations [DoI] covers the decision-making unit and its social system, while the Agricultural Innovation System [AIS] covers (external) institutional and policy aspects (Gunter, Moore, Eubank \& Tino, 2016) which frame farmers' decisions. The DoI and AIS frameworks embrace perspectives of developing-country agriculture (Spielman, 2005; Ndah et al., 2014), hence are appropriate for the analysis, which focuses on Malawi. In addition to contributing unique but complementary perspectives on dis-adoption, the two theories are widely used in determining adoption of agricultural innovations including CA (e.g. Lalani, Dorward, Kassam \& Dambiro, 2017; Corbeels et al., 2014).

\section{Diffusion of innovations [DoI]}

DoI is a meta-theory comprising the innovation decision process, individual innovativeness, rate of diffusion and perceived attributes of an innovation (Rogers, 2003). The innovation decision process framework characterises the five stages passed through when a decision maker is adopting an innovation: 1) knowledge stage; 2) persuasion stage; 3) decision stage; 4) implementation stage; and 5) confirmation stage (Rogers, 2003, p.170). This article focuses on implementation and confirmation stages of the innovation decision process whereby perceived new innovations are put into practise, and it is also where challenges on use of the innovation often emerge (see Moser \& Barrett, 2003; Neill \& Lee, 2001). As the innovation is being utilised, real experiences and perceptions arise, a process out of which dis-adoption is a possible outcome (Rogers, 2003). Analyses of the implementation stage are generally lacking in adoption literature despite its significance in conceptualising or determining (dis)adoption. The (dis)adoption decision process is largely informed by perceived attributes of the innovation such as perceived complexity; relative advantage; compatibility with felt needs, existing (farm) management regime, beliefs or values; personal experiences (mainly during implementation stage) and nature of the social-political system (Pannell et al., 2006; Ndah et al., 2012). These themes guided the methodological approach of our study.

\section{Agricultural Innovation System}

An agricultural innovation system [AIS] is a network of actors, organisations and/or individuals, together with supporting institutions and policies in agricultural and related sectors, which brings existing or new products, processes and forms of organisation into economic and social use (Aerni, Nichterlein, Rudgard \& Sonnino, 
2015). Employing the AIS framework is intended to address the problem of linearity inherent in past national research systems and agricultural knowledge and information systems approaches (Anandajayasekeram, 2011). AIS emphasises the notion that innovations need not only originate from designated national research institutions, but also from various system actors, including smallholder farmers. The AIS is said to accentuate social learning through knowledge co-production and sharing among various actors along the research-extension-user pathway, as well as creating a conducive environment to foster such dynamic interactions. The AIS uses systems approach as it recognises the value of multi-directional interactions in technology generation, dissemination and use, processes of institutional learning and change, and seeks to integrate multiple sources of knowledge and innovation (Spielman, 2005; World Bank, 2012).

AIS comprises three main interconnected clusters: 1) agricultural research and education systems; 2) bridging institutions; and 3) agricultural value chain actors and organisations (Spielman \& Birner, 2008). The AIS approach involves different actors working in a dynamic and interactive manner, all contributing to the production, distribution, processing or value-addition and marketing of agricultural goods and services (Ndah et al., 2014). It has been widely demonstrated in the literature that the AIS framework is a useful guiding tool in the identification of key stakeholders, policies or coordinating mechanisms within the agricultural system, and can help to diagnose system components, helping to inform policy decisions (e.g. Dougill et al., 2017; Gunter et al., 2016; Hermans, Stuiver, Beers \& Kok, 2013, 2013; Hall, Mytelka \& Oyeyinka, 2006). The AIS framework also provides an effective guide for examining structures, capacity, operations and processes of the various organisations governing the relevant agricultural system, often overlooked in linear technology generation and transfer approaches (Kaluzi, Thierfelder, \& Hopkins, 2017).

\subsection{Study Area}

The study was conducted in Malawi's two districts of Lilongwe and Dowa (Figure 1). Malawi was chosen because its economic performance and livelihoods of the people are directly linked to performance of the agricultural sector (Mwase et al., 2014), hence agricultural interventions such as CA are intensively promoted to address various production and social-economic constraints facing the country (Khataza, Doole, Kragta \& Hailu, 2018). 


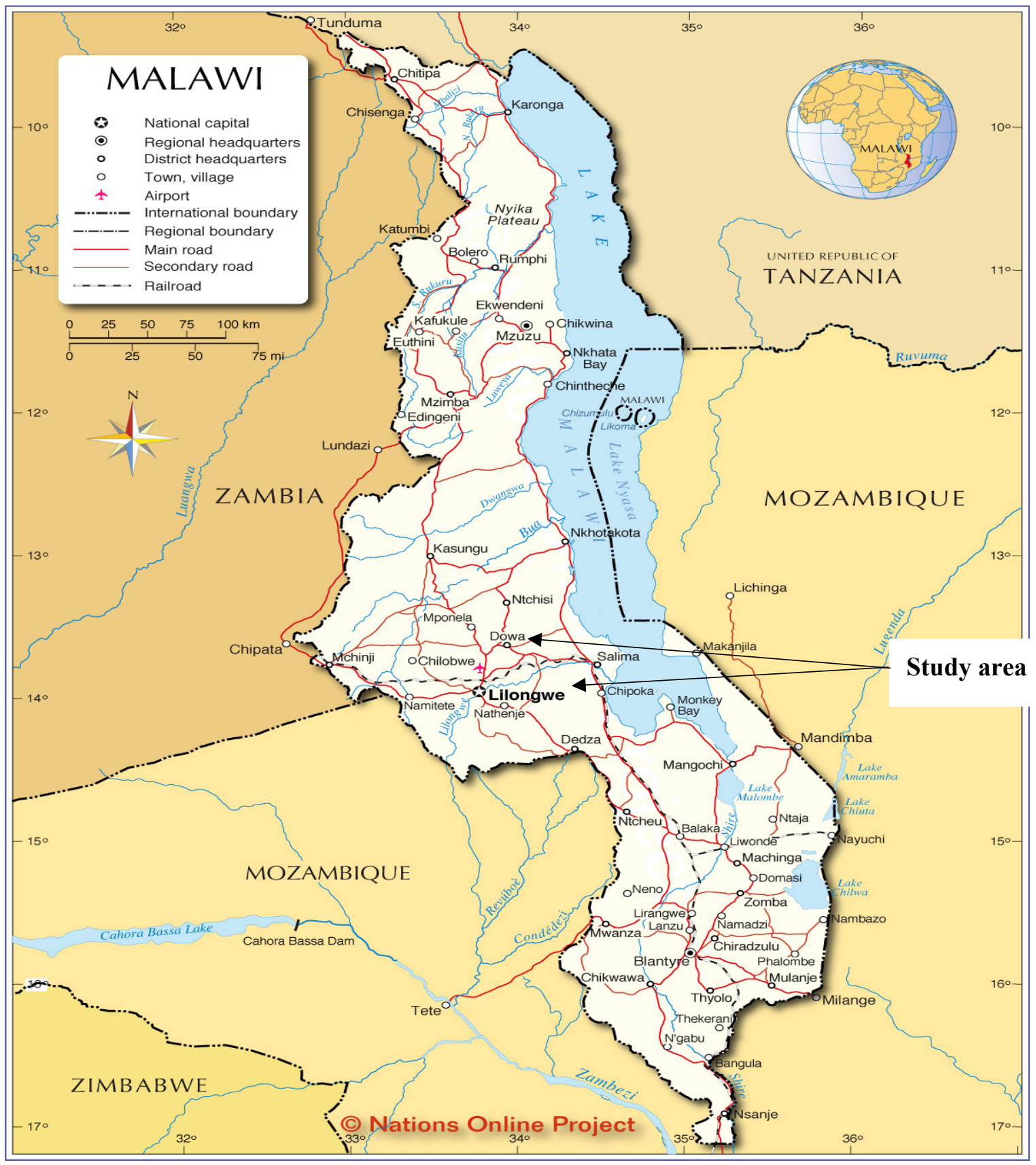

Figure 1. Map of Malawi showing study area

Source: Google Maps

Lilongwe and Dowa Districts were purposively selected in consultation with the Department of Land Resources and Conservation, for several reasons: (1) there is dominant CA project activity in the districts. With Government and multiple non-governmental organisations (NGOs) implementing CA projects in the same Districts, our study areas were suitable for exploring institutional arrangements in CA dissemination to farmers; (2) the Districts had a presence of potential respondents with the requisite experience as CA has been implemented for over five years. As such, study participants had useful depth of CA experience relevant to the research question; (3) the Districts experience challenges in sustaining smallholder farmers' continued adoption of CA. Maize (Zea mays) is the main food crop while tobacco (Nicotiana tabacum L.) is the main cash crop. Leguminous crops such as soy bean (Glycine max), common bean (Phaseolus vulgaris) and groundnuts (Arachis hypogaea L.) are also grown. Mixed crop-livestock farming systems dominate the area, with common livestock being chickens and goats, and to a lesser extent pigs and cattle. Lilongwe and Dowa Districts have a unimodal 
rainfall pattern, annually averaging 900 and $1250 \mathrm{~mm}$, with an annual temperature range of $20-28^{\circ} \mathrm{C}$ and $15-30^{\circ} \mathrm{C}$ respectively (Malawi Government, 2012).

\subsection{Methods}

We used a mixed methods approach (Tashakkori \& Teddlie, 2010) to comprehensively investigate pathways to CA dis-adoption in Malawi. This comprised key informant interviews (Hay, 2010), questionnaire surveys (Bryman, 2016), focus group discussions [FGD] (Ryan, Gandha, Culbertson \& Carlson, 2014) and policy analysis (Young, 2002). To identify key informants for interview, an inventory containing all CA stakeholders in Malawi's CA innovation system was compiled in collaboration with Malawi's Department of Land Resources and Conservation, the host department of the National Conservation Agriculture Task Force [NCATF]. From that list, prominent CA stakeholders at national level were purposively selected and validated by the relevant District Agriculture Development Office. Purposive sampling (Onwuegbuzie, Dickinson, Leech \& Zoran, 2009) was used to identify experts for interviews to understand if and how institutional arrangements of CA promoters lead to dis-adoption. 52 key informants with in-depth knowledge of CA (gained through first-hand experience in the following diverse stakeholder groups: CA promotion or implementation, training, research, education, policy-making process, funding, advocacy or farm input supply) were interviewed face to face. Key informants between the groups were chosen using snow-ball sampling (Hay, 2010). To minimise bias, key informants were requested to suggest individuals with alternative views on CA. Next, in-depth interviews were conducted with 10 key informants from Government and NGOs (as prominent CA promoters) to get insight into their organisational capacity, CA delivery mechanisms, interactions with other promoters and challenges encountered. Follow-up interviews were done with prominent stakeholders in the CA innovation system for triangulation purposes and to enhance the breadth, depth, and richness of information with diverse interpretations (Baxter \& Eyles, 1997).

To identify respondents for questionnaires and FGDs, purposive sampling was used to identify smallholder farmers with at least two years' experience in CA to obtain rich and relevant data (two years is Malawi's definition of CA adoption set by the NCATF). Purposive sampling was used so that only smallholders who were still practising CA for a minimum of two years at the time of data collection or those who had practised CA for at least two years but had dis-adopted were targeted. 300 questionnaires were administered face to face, from which suitable participants and themes for FGDs were selected (Table 1). Selection of FGDs was selected based on farmers' in-depth knowledge of CA demonstrated during the survey, willingness, and consent given to participate in group discussions.

To identify policies to help us address our aim, we used purposive sampling. What matters most in the choice and sample size of text for policy analysis is "richness of textual detail" (Waitt, 2010, pp 222) and its relevance to research aims (Baxter \& Eyles, 1997), so, we selected documentary materials shown in Table 1 for in-depth analysis.

Table 1. Data analysed to determine drivers of CA dis-adoption among smallholder farmers

\begin{tabular}{|c|c|c|c|}
\hline $\begin{array}{l}\text { Data collection } \\
\text { method }\end{array}$ & Description & Location & $\begin{array}{ll}\text { Number } & \text { of } \\
\text { respondents/remarks }\end{array}$ \\
\hline $\begin{array}{l}\text { Key } \\
\text { informants' } \\
\text { interviews }\end{array}$ & $\begin{array}{l}\text { These were done with stakeholders on their role in } \\
\text { CA, knowledge, perspectives, challenges \& possible } \\
\text { solutions }\end{array}$ & National & 52 \\
\hline $\begin{array}{l}\text { In-depth } \\
\text { interviews }\end{array}$ & $\begin{array}{l}\text { Interviews were done with CA promoters on their } \\
\text { organisational capacity, CA delivery mechanisms, } \\
\text { collaboration efforts, challenges \& possible solutions }\end{array}$ & $\begin{array}{l}\text { Lilongwe } \\
\text { \& Dowa }\end{array}$ & 10 \\
\hline $\begin{array}{l}\text { Questionnaire } \\
\text { surveys }\end{array}$ & $\begin{array}{l}\text { Surveyed smallholder farmers on agronomic } \\
\text { practices, CA practices implemented, challenges and } \\
\text { CA extension delivery }\end{array}$ & $\begin{array}{l}\text { Lilongwe } \\
\text { \& Dowa }\end{array}$ & 300 \\
\hline $\begin{array}{l}\text { Focus group } \\
\text { discussions } \\
\text { (FGDs) }\end{array}$ & $\begin{array}{l}\text { Discussed with smallholder farmers on CA project } \\
\text { implementation, CA benefits \& challenges, } \\
\text { engagement with agricultural advisory service } \\
\text { providers and smallholders' views on CA }\end{array}$ & $\begin{array}{l}\text { Lilongwe } \\
\text { \& Dowa }\end{array}$ & $\begin{array}{l}8 \text { FGDs (maximum } \\
\text { participants/group: } 14, \\
\text { minimum 7) }\end{array}$ \\
\hline $\begin{array}{l}\text { Follow-up } \\
\text { interviews }\end{array}$ & Follow-ups with prominent key informants & National & 17 \\
\hline
\end{tabular}




$\begin{array}{llll}\text { Policy analysis } & \begin{array}{l}\text { Document analysis of national policy documents: } \\ \text { National Agriculture Policy (Malawi Government, } \\ \text { 2016), Agriculture Sector-wide Approach (Malawi }\end{array} & \begin{array}{l}4 \text { policy } \\ \text { analysed } \\ \text { integration } \\ \text { Government 2010), Guide to Agricultural Production } \\ \text { and Natural Resources Management (Malawi }\end{array} & \begin{array}{r}\text { documents } \\ \text { for } \\ \text { and }\end{array} \\ \text { Government 2012), Guidelines for Implementation } \\ \text { of Conservation Agriculture in Malawi (NCATF, } \\ \text { 2016) }\end{array}$

Data from survey questionnaires were analysed using SPSS (v20). Qualitative data from interviews and FGDs were transcribed and analysed using thematic analysis (Bryman, 2016). Analysis of documentary materials was achieved by using thematic content analysis (Hay, 2010). Robustness of the mixed methods used in this study generated valuable insights that comprehensively mapped out pathways to CA dis-adoption by smallholder farmers in Malawi.

\section{Results}

\subsection{Conceptualisation Framework of CA Dis-Adoption Drivers}

Results revealed drivers of dis-adoption at higher level (national policy drivers), intermediary (institutional drivers) and lower levels (smallholders' social-cultural environment) of the CA innovation system. Figure 2 shows an integrated map of the drivers, termed the CA dis-adoption drivers framework, which illustrates the multiple pathways to CA dis-adoption by Malawi's smallholder farmers. 


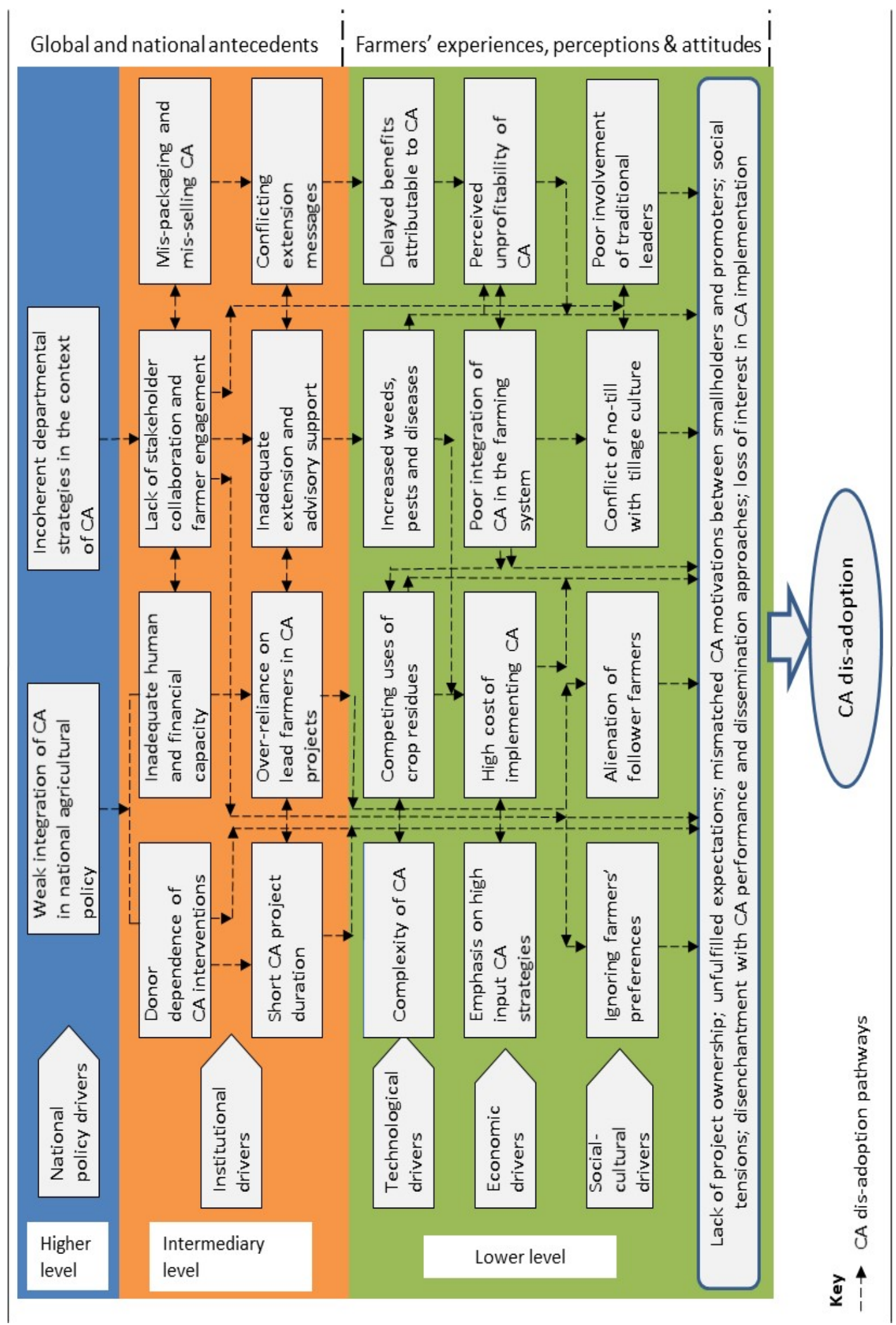

Figure 2. CA dis-adoption drivers framework

The CA dis-adoption drivers framework demonstrates that understanding dis-adoption requires consideration of multiple drivers in policies, promoters' institutional arrangements and farmers' experiences and perceptions. The following section details the various elements of the framework and illustrates the role of the various dimensions 
and layers of dis-adoption drivers across rural Malawi.

\subsubsection{National Policy Drivers of Dis-Adoption}

Higher level dis-adoption drivers were derived from analysis of coherence and integration of CA into national policies. Synthesis of our findings reveals that weak CA integration in key policies and lack of coherence in Malawi's agricultural policies and/or their implementation arrangements, exert a critical influence on dis-adoption by propagating institutional inefficiencies that undermine farmers' continued adoption of CA.

\section{Weak integration of $C A$ in agricultural policies}

Integration of CA in the National Agricultural Policy was weak, as it was not explicitly mentioned in the broader policy direction (policy goals, objectives and priority areas) but only in implementation plans to "promote investments in climate smart agriculture and sustainable land and water management" (Malawi Government, 2016, p28). Considering that national priorities are clearly reflected in the broader statements of national policies, and therefore receive priority budgetary allocations (Lasco, Cruz, J. Pulhin \& F. Puhlin, 2006), the absence of CA at higher policy levels shows a lack of high-level political will to ensure sufficient allocation of funding for CA. This is confirmed by one key informant: "Budget ceilings for important items such as fuel and allowances are reached before the end of the financial year" (District Subject Matter Specialist). Hence, CA projects are subject to limited resources and short-durations which is unhelpful as CA benefits take time to accumulate (Findlater et al., 2019).

The weak integration suggests that CA has not (yet) been strongly embraced by the Malawian government as a priority strategy for advancing agricultural development. It also signifies that CA experts fail to effectively engage with relevant policy making mechanisms and advance understanding and knowledge of CA among key policy stakeholders, especially in the government hierarchy. As power and politics shape policy outcomes (Nightingale, 2017) such that driving the policy agenda demands 'closer proximity to the decision-making body' (Wamsler, 2017), poor engagement of influential contacts in agricultural policy formulation arguably contributed to weak integration of CA in national policies. Consequently, implementation of CA activities is subject to inadequate resources.

\section{Lack of coherence in agricultural policies}

Lack of coherence around CA in Malawi's agricultural strategies was common in all policies we analysed and also reflected in interview data: "Department of Land Resource [and Conservation] is advancing no-till [system] while the Department of Crops is advocating ploughs and ridgers through its tractor hire scheme in all ADDs [Agricultural Development Divisions]. The same Department of Land Resource is implementing CA on one hand and advancing residue soil incorporation, contour ridging on the other; this is happening within the same Ministry [Ministry of Agriculture, Irrigation and Water Development" (Senior Civil Society Official. Incoherent policies contribute to dissemination of conflicting extension messages which confuse smallholder farmers who consequentially lose interest in CA altogether (Figure 2).

\subsubsection{Institutional Drivers of Dis-Adoption}

There are dis-adoption drivers emanating from institutional arrangements of CA promoters. We found these drivers to be key moderators of policies, farmers' experiences and perceptions in the innovation system, and a central constituent in framing understanding of CA dis-adoption. Results revealed three major dis-adoption drivers in institutional arrangements of CA promoters: donor dependence of CA projects; financial and human capacity shortfalls; and lack of stakeholder collaboration at the local level.

\section{Donor dependence of CA interventions}

Our findings show that $\mathrm{CA}$ in Malawi overly relies on funding from international donor agencies, which subjects CA to donor-prescribed short project durations of three years or less: "We are currently implementing an 18 months' project. It used to be 5 years, then 3 years, now it's 18 months; I wonder what comes next" (NGO Manager). Such short project durations are unsuitable considering that farmers have to practise CA for up to five years before realising tangible benefits of soil improvement and yield increases (Pittelkow et al., 2015; Corbeels et al., 2014). Consequently, there is limited buy-in and premature discontinuation of CA amongst many smallholders who generally expect quick benefits (Baudron, Thierfelder, Nyagumbo \& Gerard, 2015). In addition, some promoters utilise expert-led, top-down approaches, evidenced by the following FGD comment: "We, as a community, chose to have a borehole [during pre-project consultations] but they brought us this CA instead" (FGD member, Dowa). Such top-down approaches inevitably undermine ownership and sustainability of projects (Wood, Dougill, Quinn \& Stringer, 2016). As funding recepients have to show positive results quickly to maintain donor support, promoters often concentrate their efforts in the same areas where farmers have had 
previous project experience: "Every $N G O$ is introducing $C A$ in these areas yet there are other parts in our that have never seen [never had] an NGO [project]" (District Executive Committee Official). As competition beneficiaries increases under such circumstances, CA promoters resort to unsustainable use of incentives to draw more beneficiaries: "It appears that the NGO that gives more incentives gets more beneficiaries" (Agricultural Development Division Extension Officer). However, such a 'push' strategy only encourages the proliferation of serial dis-adopters, as $82 \%$ of survey respondents $(\mathrm{n}=300)$ stated that they could not continue practising CA without incentives, confirmed in FGDs: "I cannot do CA without receiving something" (FGD member, Hence competition for project beneficiaries among CA promoters leads farmers to continuously move from one project to the next in search of more or better incentives.

\section{Human and financial capacity shortfalls of CA promoters}

Prevalent shortfalls in human capacity of CA promoters undermines the quality and intensity of extension service support to farmers. However, low staffing levels and low motivation of frontline extension staff were frequently cited challenges during interviews. We calculated that in the study districts, the ratio of extension officer:farm family was 1:2688, contrary to government recommended ratio of 1:500. This means that extension visits to CA farms are not only infrequent but often brief as the officers usually travel long distances, mostly on foot or by bicycle, to reach farmers, and are often responsible for extensive geographical areas (cf. Nyanga, 2012). Hence, extension officers spend very little time interacting face to face with farmers to reinforce CA knowledge and skills, despite many requiring more intensive extension support (Chinseu et al., 2019). While enrolment of lead farmers (Note 1) is generally regarded as a remedy for problems of acute extension shortages, the strategy is not suited to CA promotion. Having limited hands-on CA training: "It's impossible for me to master all the CA activities just by listening [in a classroom]" (Lead farmer, Dowa), lead farmers are unable to offer effective extension and advisory support to their peers, given the complexity and knowledge-extensive nature of CA (Nyanga, Johnsen, Aune \& Kalinda, 2011). Lead farmers are, in many instances, overwhelmed by technical CA demands amidst limited supervisory support. This compromises the quality and integrity of technical messages delivered. As smallholders fail to appropriately implement CA, expected benefits such as those recorded in Thierfelder et al., (2016) often do not materialise; thus farmers fail to justify their continued practicing of CA.

Limited financial resources predominantly constrain service delivery for some CA activities: "They [CA promoters] always bring demonstration inputs [seed and fertilisers] late and hardly come to see progress [of CA demonstrations]" (Agricultural Extension Officer). Late delivery of inputs denotes late planting, which according to Baudron et al. (2012) reduces yields. Also, reduced mobility of extension workers and reduced numbers of demonstration plots are mostly associated with limited financial resources. Demonstration plots act as open classrooms where farmers exchange knowledge, experiment and 'learn by doing' (Kwayu, Sallu \& Paavola, 2014) hence, a reduction in demonstrations limits farmers' access to vital learning platforms for reinforcing knowledge and skills necessary for effective CA implementation. Limited resources translate into shorter project durations and brief distribution of incentives to selected CA smallholders, both of which result in dis-adoption.

\section{Lack of CA stakeholder collaboration}

While the AIS framework regards stakeholder collaboration as a key element in technology dissemination and utilisation (Aerni et al., 2015), findings reveal a predominant lack of collaboration among CA promoters at the local level. For instance, some NGOs by-passed government structures established to coordinate district agricultural extension and development activities: "We have well defined District Assembly stakeholder panels but very few NGOs use them; the majority just go straight to the farmer, undermining our efforts" (District Assembly Extension Coordinating Committee Official). Such a tendency constitutes institutional failure which undermines the collaborative spirit whilst fuelling mixed message delivery (Gunter et al., 2016). Government extension officers were reluctant to take over expiring NGO projects since they felt 'sidelined' during inception and implementation stages: "NGOs have a tendency of bringing projects but don't want to work with us but at the end of their short-lived projects, they want government to come in and take over their sites" (District Extension Officer). As most NGOs only have temporary structures through which various interventions are implemented, lack of collaboration, particularly with government, leaves many farmers without reliable access to technical advisory services. This means they lack the support necessary to effectively continue practicing CA beyond the project period.

\subsubsection{Technological Drivers of Dis-Adoption}

Delayed benefits from CA; increased weeds, pests and diseases; and complexity of CA are the main technological drivers of CA dis-adoption among smallholders in Malawi. 


\section{Delayed benefits from $C A$}

While CA is primarily marketed on the basis of its potential to increase yields, $51 \%$ of survey respondents $(\mathrm{n}=300)$ reported no yield increase under $\mathrm{CA}$. Those that dis-adopted significantly perceived that their yields did not increase under CA $\left(\mathrm{X}^{2}=27.011, \mathrm{p}=0.000\right)$. 'Failure to experience CA benefits' is a common sentiment expressed by smallholder farmers in sub-Saharan Africa (Gunter et al., 2016; Pedzisa et al., 2015). Tangible benefits may only become observable after a longer period of time due to CA's inherent attributes (see Andersson \& Giller, 2012; Baudron et al., 2012 \& 2015). As a result, there is often a mis-match between farmers' expectations and attributes of CA (see Findlater et al., 2019; Pannell, Llewellyn \& Corbeels, 2014). 74\% of FGD participants $(\mathrm{n}=82)$ also expressed that $\mathrm{CA}$ failed to deliver rewards 'pompo pompo' (instantly). Consequently, many smallholders get frustrated often replacing CA with other enterprises perceived to produce instant benefits. In our study, some respondents replaced CA with dairy production: "I would rather feed maize stalks to my cows than use them for CA because the reward from milk sales is pompo-pompo [instant]" (FGD Member, Lilongwe). This demonstrates critical dis-adoption interconnections between technology attributes, promoters' dissemination approaches, and farmers' experiences.

\section{Increased weeds, pests and diseases associated with CA}

Increase in weeds, pests and diseases were common challenges smallholders encountered as they practised CA. $45 \%$ of respondents $(n=141)$ reported an increase of weeds in their no-till fields whereas $16 \%(n=271)$ felt that mulch brought pests and diseases into their fields. Such challenges have also been observed elsewhere (e.g. Findlater et al, 2019; Khataza et al., 2018; Kirkegaard et al., 2014). What exercerbated the situation in our study areas was that whilst farmers faced such technological challenges, extension advisory support remained limited. Poor crop yields under CA persisted yet costs associated with control of pests and diseases continued to rise. The disparity between farmers' expectations (e.g. saving labour, low production costs and high yields as indicated in CA promotional messages) and actual experiences led many to lose interest and to dis-adopt CA.

\section{Complexity of CA}

While CA requires several agronomic practices applied simultaneously, $25 \%$ of survey respondents $(\mathrm{n}=300)$ stated that implementing such regimented activities was too involving. Considering that strict adherence to the core principles is central in most CA projects in Malawi (Kaluzi et al., 2017), many smallholders are reluctant to expand their CA fields. Area under CA for $83 \%$ of questionnaire respondents $(\mathrm{n}=300)$ remained at $0.01 \mathrm{ha}$. The underlying issue as regards complexity of CA is inadequate technical knowledge among smallholders amidst low/no mechanisation and poor advisory support from extension agents. These findings suggest that promoting rigid CA prescriptions may not be well suited to smallholders because it hinders efforts to package CA in line with local needs, interests and context, leading to subsequent dis-adoption.

\subsubsection{Social-Cultural Drivers of Dis-Adoption}

Three major social-cultural drivers were found to influence smallholder farmers' decisions to dis-adopt CA: alienation of follower farmers in CA clubs; deep-rooted tillage culture in smallholder farming communities and social tensions, particularly relating to mulch materials.

\section{Alienation of follower farmers in CA clubs}

Concentration of project resources on lead farmers, such as training, provision of farm inputs, allowances (disguised as 'reimbursements'), bicycles or extension visits, instigated a feeling of alienation amongst follower farmers: "Imagine, our lead farmer was given a bicycle and he gets free fertilisers, seeds, an allowance but for us, what do we benefit?" (FGD Member, Dowa). The perceived unequal distribution of resources in CA projects results in conflicts and withdrawal of members. $44 \%$ of survey respondents $(n=300)$ herein withdrew from CA clubs mostly due to lack of conflict resolution skills amongst the group leadership. Under such circumstances, keeping project members long-term becomes challenging, let alone expanding the membership base.

\section{Tillage culture in smallholder farming communities}

The deep-rooted land preparation culture of clearing land, tilling and ridging before planting crops compromises wider acceptability of CA among some smallholder farming communities in Malawi. This tradition stands at odds with no-till, which is the most common practice advocated under the CA pillar of minimum soil disturbance (Kassam et al., 2019), and even deemed "non-negotiable" (NCATF, 2016, p9) in Malawi's CA guidelines. This suggests that CA promoters fail to actively and genuinely engage with local communities to properly contextualise CA interventions. To illustrate this point, our findings indicate that vernacular translation CA as 'mtayakhasu' (abandon the hoe), in communities with tillage culture where the hoe is a valued symbol of a 'hard working farmer' (Chinseu et al., 2019), weakens the support of traditional leaders and general buy-in from the 
wider community. As people generally endeavour to conform to norms of society (Rogers, 2003) and avoid being labelled mlesi (lazy), farmers practise no-till only on small portions of their farmland (just to be part of the CA project) while the rest is under conventional tillage (Mazvimavi \& Twomlow, 2009). In addition, tillage practices provide ganyu (on-farm piece work) which is highly valued as an annual coping mechanism in rural smallholder farming communities to enable households to purchase food. While strict no-till proponents discourage ploughing or digging, poor households that depend on ganyu to survive food shortage periods are negatively affected. As such, participation in rigid CA projects that seem to ignore the importance of tillage in rural societies is often devoid of genuine commitment and dis-adoption becomes inevitable.

\section{Social tensions related to mulch materials}

Due to (distorted) agricultural extension messages suggesting dead mulch from crop residues is the only way of maintaining soil cover, farmers face various social challenges concerning mulch materials as they practice CA. For example, other vernacular translations of CA revealed in our study, namely: ulimi wa mapesi (farming that applies maize stalks), ulimi wa m'phimbira (farming that uses mulch) or ulimi wa bulandi (farming that applies a thick mulch) instilled the misconception that farmers cannot continue with CA when mulch materials become unavailable or lost. We found scarcity of mulch materials to be a common challenge, reported by $51 \%$ of respondents $(\mathrm{n}=271)$, yet farmers frequently lost their crop residues laid for mulching in their CA fields to acts of sabotage, mainly deliberate torching or theft. Competing uses of crop residues compound the issue of mulch sabotage, hence farmers get frustrated, particularly where support of traditional leaders is lacking or where measures or bylaws to protect CA fields are not enforced (Kaluzi et al., 2017). As distorted extension messages make farmers believe they can only practice CA using dead mulch, persistent loss of mulch laid in CA fields becomes unbearable and many farmers settle on dis-adopting CA because they cannot practice mulching as required by promoters. As the name of an innovation structures perceptions and determines compatibility with societal norms and values, incorporating local contexts in project interventions becomes even more paramount.

\subsubsection{Economic Drivers of Dis-Adoption}

Emphasis on high input CA and poor integration of CA into the wider livelihood options of smallholder communities constitute major economic drivers of CA dis-adoption.

\section{Emphasis on high input $C A$}

While the vast majority of smallholder farmers' annual incomes are relatively very low (FAO, 2018), promoters emphasise use of hybrid seed, inorganic fertilisers, herbicides and other agrochemicals in CA, considered expensive by $7 \%$ of survey respondents $(n=300)$. This suggests lack of convergence between the core approach of current CA interventions and the economic realities of smallholders. Although CA projects help farmers to get off the ground by providing input grants in the initial year of implementing $\mathrm{CA}$, many fail to acquire the required inputs in subsequent years when such grants are withdrawn. Associating CA with inorganic inputs (e.g. Thierfelder et al., 2016), entrenches the perception that CA is unaffordable in the absence of external input support and causes farmers to believe that they cannot implement CA without them. In alignment with Nyanga (2011), this research shows that such perceptions encourage a dependency mentality among smallholders, who mostly practice CA for as long as they receive project input support; evidenced in this study by $21 \%$ of respondents $(\mathrm{n}=300)$ who dis-adopted simply because the project stopped issuing farm inputs.

\section{Poor integration of $C A$ in the farming system}

Owing to poor integration in the farm system and taking into account the diversity of livelihood options available in smallholder farming communities, CA is largely perceived to compete with farmers' other income generating opportunities. This is exemplified by perceived conflict between CA and other enterprises: "To me, CA was just too involving, it was very difficult for me to do my business [locally brewed liquor] and CA simultaneously" (FGD Member, Lilongwe). Failure of promoters to facilitate proper integration of CA and enterprises such as livestock encourages competition for crop residues, when the two enterprises could be mutually reinforcing if properly integrated (see Thornton et al., 2018). Due to promoters' inability to deliver extension messages in a way that highlights synergies among livelihood options in the farm system, smallholder communities often view CA as competing with, rather than complementing, other enterprises. Under such circumstances, smallholders prioritise allocation of resources (e.g. time, money, labour, crop residues) to those enterprises that appear to be instantly more rewarding. As CA is usually judged to be less appealing in the short-term due to the long-time lag before benefits are received, dis-adoption often follows.

The CA dis-adoption drivers framework illustrates that shortcomings in institutional arrangements are a common factor influencing dis-adoption drivers across the spectrum. Without suggesting that institutional arrangements 
are sole drivers of CA dis-adoption, their central role in the CA innovation system in moderating smallholder farmers' experiences, perceptions, and ultimately influencing dis-adoption decisions, is clearly evident in the findings of this research. Dis-adoption drivers across the spectrum often have multiple underlying dimensions and layers linking to promoters' institutional arrangements (Table 2).

Table 2. Illustration of institutional drivers as a common factor in dis-adoption drivers

\begin{tabular}{|c|c|}
\hline $\begin{array}{l}\text { Description of CA dis-adoption } \\
\text { driver }\end{array}$ & $\begin{array}{l}\text { Illustration of underlying shortcoming(s) in institutional arrangemen } \\
\text { contributing to the dis-adoption driver }\end{array}$ \\
\hline $\begin{array}{l}\text { Weak integration of } \mathrm{CA} \text { in } \\
\text { agricultural policies }\end{array}$ & $\begin{array}{l}\text { Weak advocacy of CA in the policy arena; lack of broader understanding of } \\
\text { CA among policy stakeholders; lack of political will to advance CA in key } \\
\text { policy objectives }\end{array}$ \\
\hline Incoherent agricultural strategies & $\begin{array}{l}\text { Poor sectoral/departmental inter-linkages and coordination; lack of } \\
\text { harmony in departmental strategies in the context of CA }\end{array}$ \\
\hline $\begin{array}{l}\text { Donor dependence of } \mathrm{CA} \\
\text { interventions }\end{array}$ & $\begin{array}{l}\text { Aligning CA with international donor agendas; imposing CA on farmers; } \\
\text { emphasising high-input CA; short project cycles }\end{array}$ \\
\hline $\begin{array}{l}\text { Human capacity shortfalls of } \mathrm{CA} \\
\text { promoters }\end{array}$ & $\begin{array}{l}\text { Bottlenecks in organisational structures of the extension system; high staff } \\
\text { turnover in government extension system; low ratios of extension agent: } \\
\text { farm families; inadequate extension service }\end{array}$ \\
\hline $\begin{array}{l}\text { Lack of } \mathrm{CA} \\
\text { collaboration }\end{array}$ & $\begin{array}{l}\text { Competition for project beneficiaries among CA promoters; by-passing } \\
\text { district stakeholder collaboration platforms; top-down approach }\end{array}$ \\
\hline Delayed benefits from CA & $\begin{array}{l}\text { Misrepresented extension messages raising unrealistic expectations among } \\
\text { farmers }\end{array}$ \\
\hline Complexity of CA & $\begin{array}{l}\text { Inadequate extension and advisory support; rigid set of practices in CA } \\
\text { design }\end{array}$ \\
\hline $\begin{array}{l}\begin{array}{l}\text { Conflict with smallholder tillage } \\
\text { culture }\end{array} \\
\end{array}$ & Emphasis on rigid no-till system; ignoring local values/interests \\
\hline Social tensions & $\begin{array}{l}\text { Encouraging use of dead mulch as the only source of soil cover; } \\
\text { concentrating resources on lead farmers as followers feel alienated }\end{array}$ \\
\hline High input CA strategies & Associating CA with hybrid seeds, inorganic fertilisers and herbicides \\
\hline $\begin{array}{l}\text { Poor integration of } \mathrm{CA} \text { in the farm } \\
\text { system }\end{array}$ & $\begin{array}{l}\text { Lack of contextualisin } \\
\text { limited engagement wit }\end{array}$ \\
\hline
\end{tabular}

The finding that institutional arrangements are central in driving CA dis-adoption, suggests that reducing dis-adoption not only requires improvement in economic and biophysical attributes of the technology, but more importantly, such efforts need to be coupled with improvements in how promoters implement CA projects. This includes rethinking their dissemination approach, organisational capacity and collaboration with pertinent stakeholders, including smallholders. In this regard, (dis)adoption studies need to further widen their perspective on understanding how broader institutional factors in the innovation system influence farmers' experiences and perceptions, rather than considering farm-household level or biophysical determinants independently. In the same vein, broader CA stakeholders need to better acknowledge the role of relevant national policies and dissemination approaches in CA promotion.

\section{Discussion}

Our paper has revealed that dis-adoption is a complex phenomenon, understanding of which requires a holistic approach to unravel constraints in multiple domains including interaction of dis-adoption drivers across the CA innovation system. For instance, Figure 2 shows that dis-adoption occurs due to unfavourable experiences and perceptions of smallholder farmers as they practise CA. While unfulfilled expectations, loss of interest and/or disenchantment appear to be prevalent immediate triggers of dis-adoption, the ultimate decision to dis-adopt is fuelled by complex interactions of multi-faceted drivers originating from international, national, district and local levels of the innovation system. 
At the international level, donor agencies advance project prescriptions under short project durations that are not in tandem with the gradual impact nature of CA (see Findlater et al., 2019; Pittelkow et al., 2015). Consequently, CA is widely perceived as failing to live up to smallholder farmers' expectations (Baudron et al., 2012) because projects expire before tangible benefits emerge. Considering that $\mathrm{CA}$ is almost entirely dependent on (short-lived) funding from international donors, expert-led projects are commonplace (Wood et al., 2016), which erodes ownership and farmer satisfaction. Conversely, donor expectations of exponential adoption appear to influence promoters to work in competition and unsustainably deploy incentives to draw in farmers and out-compete each other. Repercussions of donor influence at global level result in unsuitable strategies for CA delivery at district level, undermining project implementation, and ultimately contributing to dis-adoption at local level.

At the national level, weak integration of CA in agricultural policies and incoherent agricultural strategies constrain resource availability and effectiveness of extension delivery. Poor mobilisation of financial and technical resources for CA activities ensues (see Mwase et al., 2014). Inevitably, delivery of technical and advisory services to CA farmers becomes inadequate, characterised by infrequent visits of extension personnel, despite smallholders' general perception that CA is complex (Ndah et al., 2014). Lack of regular knowledge reinforcement means that farmers have poor 'know-how' to effectively practise and benefit from CA, thus leading to frustration. In addition, delivery of mixed extension messages, largely due to incoherent agricultural policies (see Chinseu, Stringer \& Dougill, 2018), confuses CA farmers, prompting many to revert to conventional tillage practices perceived to be less complex.

At the local level, various technological and social-cultural drivers instigate CA dis-adoption among smallholder farmers. For instance, increased weeds, pests and diseases associated with CA negatively affect production (Kirkegaard et al., 2014) and can lead to loss of interest. Further, extension messages associating CA with use of dead mulch from crop residues compounds competion for the crop residues in rural communities (Khataza et al., 2018). As argued by Kaluzi et al. (2017), distorted extension messages precipitate mulch-related social tensions in CA communities such as theft and sabotage of mulch laid in CA fields; livestock grazing disputes or burning mulch by mouse hunters. Lack of flexibility in CA systems (Giller et al., 2015) is widely perceived to contravene the tillage culture of smallholders. Such contradictory dissemination approaches (at district level) exacerbate social tensions and perceived incompatibility of CA, dis-incentivising continued adoption of CA.

Our research further reveals that the institutional arrangements of CA promoters exert critical influence in the environment of smallholder farmers and are central in illuminating drivers of dis-adoption in the CA innovation system (Table 2). While dis-adoption drivers radiate from multiple domains and levels of the innovation system, immediate triggers of dis-adoption (i.e. lack of ownership, loss of interest or disenchantment) are manifested largely through institutional deficiencies of CA promoters. While stakeholders need to acknowledge the multi-faceted nature of CA dis-adoption, particular focus is needed on minimising institutional drivers in order to achieve sustained adoption and desired project impacts.

\section{Conclusion and Recommendations}

This article has developed and synthesised an independent, empirically grounded CA dis-adoption drivers framework, anchored in Diffusion of Innovation and Agricultural Innovation System theories and the broader CA literature. This allowed us to map the underlying dis-adoption drivers in Malawi's CA innovation system. By identifying drivers in multiple domains (public policies, institutional arrangements of promoters, and farmers' experiences) and at multiple levels (global, national, and local), the framework provides a comprehensive conceptualisation of underlying drivers of dis-adoption; including their complex interactions, and how they affect smallholder farmers' experiences, perceptions, and ultimately the decision to dis-adopt CA. The framework emphasises that the complexity of drivers underlying dis-adoption decisions demands a robust examination of triggers in all three domains in order to generate a broader understanding of the multiple pathways to CA dis-adoption. The framework therefore provides dual benefits in that it not only provides a comprehensive understanding of complex dis-adoption drivers of CA, but also provides a troubleshooting guide to improve the design and implementation of project-based agricultural interventions seeking sustained adoption. While providing a succinct account of multiple pathways to dis-adoption, our article reinforces systems approaches and a shift in focus from outputs to processes in agricultural research and development.

While the dis-adoption framework has been developed in the context of CA in Malawi, it could be usefully applied more widely. It can be utilised to conceptualise dis-adoption of similar project-based innovations in agriculture, forestry and sustainable land management among smallholder farming communities across sub-Saharan Africa. 


\section{Acknowledgements}

We gratefully acknowledge the Commonwealth Scholarship Commission (United Kingdom Government) and Sustainable Agriculture Bursary, University of Leeds for sponsoring this research. This work was also supported by the Biotechnology and Biological Sciences Research Council through UK Research and Innovation as part of the Global Challenges Research Fund, AFRICAP programme, grant number BB/P027784/1.

\section{Conflict of Interest}

The authors declare no conflict of interest.

\section{References}

Aerni, P., Nichterlein, K., Rudgard, S., \& Sonnino, A. (2015). Making Agricultural Innovation Systems (AIS) Work for Development in Tropical Countries. Sustainability, 7, 831-850. https://doi.org/10.3390/su7010831

Anandajayasekeram P. (2011). The role of agricultural R\&D within the agricultural innovation systems framework. Conference working paper 6. ASTI-IFPRI-FARA Conference. Accra: ASTI-IFPRI-FARA.

Andersson, J. A., \& Giller, K. E. (2012). On Heretics and God's Blanket Salesman: Contested claims of conservation agriculture and the politics of its promotion in African smallholder farming. In J. A. Sumberg (Ed.), Contested Agronomy: Agricultural Research in a Changing World. London: Earthscan.

Arslan, A., McCarthy, N., Lipper, L., Asfaw, S., \& Cattaneo, A. (2014). Adoption and Intensity of Adoption of Conservation Farming Practices in Zambia. Agriculture, Ecosystems and Environment, 187, 72-86. https://doi.org/10.1016/j.agee.2013.08.017

Baudron, F., Thierfelder, C., Nyagumbo, I., \& Gerard, B. (2015). Where to Target Conservation Agriculture for African Smallholders: How to Overcome Challenges Associated with its Implementation? Experience from Eastern and Southern Africa. Environments, (2), 338-357. https://doi.org/10.3390/environments2030338

Baudron, F., Andersson, J., Corbeels, M., \& Giller, K. (2012). Failing to Yield? Ploughs, Conservation Agriculture and the Problem of Agricultural Intensification: An Example from the Zambezi Valley, Zimbabwe. Journal of Development Studies, 1(1), 1-28. https://doi.org/10.1080/00220388.2011.587509

Baxter, J., \& Eyles, J. (1997). Evaluating Qualitative Research in Social Geography: Establishing Rigour in Interview Analysis. Trans Inst Br Geogr, 505-525. https://doi.org/10.1111/j.0020-2754.1997.00505.x

Bryman, A. (2016). Social Research Methods (5th ed.). Oxford: Oxford University Press.

Cheesman, S., Andersson, J. A., \& Frossard, E. (2017). Does closing knowledge gaps close yield gaps? On-farm conservation agriculture trials and adption dynamics in three smallholder farming areas in Zimbabwe. Journal of Agricultural Science, 155(1), 81-100. https://doi.org/10.1017/S0021859616000095

Chinseu, E. L., Stringer, L. C., \& Dougill, A. J. (2018). Policy Integration and Coherence for Conservation Agriculture Initiatives in Malawi. Sustainable Agriculture Research, 7(4), 51-62. https://doi.org/10.5539/sar.v7n4p51

Chinseu, E., Dougill, A., \& Stringer, L. (2019). Why do smallholder farmers dis-adopt conservation agriculture? Insights from Malawi. Land Degrad Dev, 1-11. https://doi.org/10.1002/ldr.3190

Corbeels, M., Graaf, J., Ndah, T., Penot, E., Baudron, F., Naudin, K., ... Adolwa, I. (2014). Understanding the Impact and Adoption of Conservation Agriculture in Africa: A Multi-scale Analysis. Agriculture, Ecosystems and Environment, (187), 155-170. https://doi.org/10.1016/j.agee.2013.10.011

Dougill, A. J., Whitfield, S., Stringer, L. C., Vincent, K., Wood, B., Chinseu, E. L., ... Mkwambisi, D. D. (2017). Mainstreaming Conservation Agriculture in Malawi: Knowledge Gaps and Institutional Barriers. Journal of Environmental Management, 195, 25-34. https://doi.org/10.1016/j.jenvman.2016.09.076

FAO. (2018). Climate smart agriculture: Building resilience to climate change. Rome: FAO. https://doi.org/10.1007/978-3-319-61194-5

FAO, IFAD, UNICEF, WFP and WHO. (2017). The State of Food Security and Nutrition in the World 2017. Building resilience for peace and food security. Rome: FAO.

Findlater, F. M., Kandlikar, M., \& Satterfield, T. (2019). Misunderstanding conservation agriculture: Challenges in promoting, monitoring and evaluating sustainable farming. Environmental Science and Policy, 100, 47-54. https://doi.org/10.1016/j.envsci.2019.05.027

Giller, K., Andersson, J., Corbeels, M., Kirkegaard, J., Mortensen, D., Erenstein, O., \& Vanlauwe, B. (2015). 
Beyond Conservation Agriculture. Frontiers in Plant Science (article 870, vol 6). https://doi.org/10.3389/fpls.2015.00870

Glover, D., Sumberg, J., \& Andersson, J. (2016). The adoption problem: or why why we still understand so little about technological change in African agriculture. Outlook on Agriculture, 45(1), 3-6. https://doi.org/10.5367/oa.2016.0235.

Gunter, J., Moore, K. M., Eubank, S., \& Tino G. (2016). Agricultural information networks and adoption of conservation agriculture in East Africa. Journal of International Agricultural and Extension Education, 24(1), 90-104. https://doi.org/10.5191/jiaee.2016.241109.

Hall, A., Mytelka, L., \& Oyeyinka, B. (2006). Concepts and guidelines for diagnostic assessments of agricultural innovation capacity. Working paper series \#2006-017. Maastricht: United Nations University UNU Merit.

Hay, I. (2010). Qualitative Research Methods in Human Geography. Oxford: Oxford University Press.

Hermans, F., Stuiver, M., Beers, P. J., \& Kok, K. (2013). The distribution of roles and functions for upscaling and outscaling innovations in agricultural innovation systems. Agricultural systems, 115, 117-128. https://doi.org/10.1016/j.agsy.2012.09.006

Kaluzi, L., Thierfelder, C., \& Hopkins, D. W. (2017). Smallholder farmer innovations and contexts in maize-based conservation agriculture systems in Central Malawi. Sustainable Agriculture Research, 6(3), 85-105. https://doi.org/10.5539/sar.v6n3p85.

Kassam, A., Friedrich, T., \& Derpsch, R. (2019). Global spread of conservation agriculture. Int. J. Environ. Stud., 76(1), 29-51. https://doi.org/10.1080/00207233.2018.1494927

Khataza, R. B., Doole, G. J., Kragta, M. E., \& Hailu, A. (2018). Information acquisition, learning and the adoption of conservation agriculture in Malawi: A discreet-time duration analysis. Technological Forecasting \& Social Change, 132, 299-307. https://doi.org/10.1016/j.techfore.2018.02.015

Kirkegaard, J., Conyers, M., Hunt, J., Kirkby, C., Watt, M., \& Rebetzke, G. (2014). Sense and nonsense in conservation agriculture: Principles, pragmatism and productivity in Australian mixed farming systems. Agriculture, Ecosystems and Environment, 187, 133-145. https://doi.org/10.1016/j.agee.2013.08.011

Kwayu, E., Sallu, S., \& Paavola, J. (2014). Farmer Participation in the Equitable Payments for Watershed Services in Morogoro, Tanzania. Ecosystem Services, 7, 1-9. https://doi.org/10.1016/j.ecoser.2013.12.006

Lalani, B., Dorward, P., Kassam, A., \& Dambiro, J. (2017). Innovation systems and farmer perceptions regarding conservation agriculture in Cabo Delgado, Mozambique. In A. Kassam, S. Mkomwa, \& T. Friedrich, Conservation agriculture for Africa: Building resilient farming systems in a changing climate (pp. 100-126). CAB International: Wallingford.

Lasco, R., Cruz, R., Pulhin, J., \& Puhlin, F. (2006). Tradeoff Analysis of Adaptation Strategies for Natural Resources, Water, Resources and Local Institutions in the Phillipines. AIACC Working paper. Washington DC: AIACC.

Malawi Government. (2010). The Agriculture Sector Wide Approach (ASWAp): Malawi's Prioritised and Harmonised Agricultural Development Agenda. Lilongwe: Ministry of Agriculture and Food Security.

Malawi Government. (2012). Guide to Agricultural Production and Natural Resources Management. Lilongwe: Ministry of Agriculture and Food Security.

Malawi Government. (2016). National Agriculture Policy. Lilongwe: Ministry of Agriculture, Irrigation and Water Development.

Mazvimavi, K., \& Twomlow, S. (2009). Socioeconomic and institutional factors influencing adoption of conservation farming by vulnerable households in Zimbabwe. Agricultural Systems, 101, $20-29$. https://doi.org/10.1016/j.agsy.2009.02.002

Moser, C., \& Barrett, C. (2003). The Disappointing Adoption Dynamics of a Yield-Increasing, Low External-Input Technology: The Case of SRI in Madagascar. Agricultural Systems, 76, 1085-1100. https://doi.org/10.1016/S0308-521X(02)00041-0

Mwase, W., Jumbe, C., Gasc, F., Owiyo, T., Manduwa, D., Nyaika, J., .. Maonga, B. (2014). Assessment of Agricultural Sector Policies and Climate Change in Malawi- The Nexus Between Climate Change Related 
Policies, Research and Practice. Journal of Sustainable Development, 7(6), 195-203. https://doi.org/10.5539/jsd.v7n6p195

National Conservation Agriculture Task Force (NCATF). (2016). Guidelines for Implementing Conservation Agriculture in Malawi. Lilongwe: NCATF.

Ndah, H. T., Schuler, J., Uthes, S., Zander, P., Traore, K., Gama, M., ... Corbeels, M. (2014). Adoption Potential of Conservation Agriculture Practices in Sub-Saharan Africa: Results from Five Case Studies. Environmental Management, 53, 620-635. https://doi.org/10.1007/s00267-013-0215-5

Ndah, H. T., Schuler, J., Uthes, S., Zander, P.,Triomphe, B., Mkomwa, S., \& Corbeels, M. (2012). Adoption potential of conservation agriculture in Africa: a newly developed assessment approach (QAToCA) applied in Kenya and Tanzania. Land Degration and Development. https://doi.org/10.1002/ldr.2191

Neill, S. P., \& Lee, D. R. (2001). Explaining the adoption and dis-adoption of sustainable agriculture: The case of cover crops in northern Honduras. Economic Development and Cultural Change, 49(4), 793-820. https://doi.org/10.1086/452525

Nightingale, A. J. (2017). Power and politics in climate change adaptation efforts: Struggles over authority and recognition in the context of political instability. Geoforum, 84, 11-20. https://doi.org/10.1016/j.geoforum.2017.05.011

Nyanga, P. (2012). Factors Influencing Adoption and Area under Conservation Agriculture: A Mixed Methods Approach. Sustainable Agriculture Research, 1(2), 27-40. https://doi.org/10.5539/sar.v1n2p27

Nyanga, P. H., Johnsen, F. H., Aune, J. B., \& Kalinda, T. H. (2011). Smallholder farmers' perceptions of climate change and conservation agriculture. Journal of Sustainable Development, 4(4), 73-85. https://doi.org/10.5539/jsd.v4n4p73

Oladele, O. (2005). A tobit analysis of propensity to discontinue adoption of agricultural technology among farmers in Southwestern Nigeria. Journal of Central European Agriculture , 6(3), 249-254

Onwuegbuzie, A. J., Dickinson, W. B., Leech, N. L., \& Zoran, A. G. (2009). A Qualitative Framework for Collecting and Analyzing Data in Focus Group Research. International Journal of Qualitative Methods, $8(3), 1-21$.

Pannell, D. J., Llewellyn, R. S., \& Corbeels, M. (2014). The farm-level economics of conservation agriculture for resource-poor farmers. Agriculture, Ecosystems and Environment, 187(1), 52-64. https://doi.org/10.1016/j.agee.2013.10.014.

Pannell, D. J., Marshall, G. R., Barr, N., Curtis, A., Vanclay, F., \& Wilkinson, R. (2006). Understanding and promoting adoption of conservation practices by rural landholders. Australian Journal of Experimental Agriculture, 46, 1407-1424. https://doi.org/10.1071/EA05037

Pedzisa, T., Rugube, L., Winter-Nelson, A., Baylis, K., \& Mazvimavi, K. (2015). Abandonment of conservation agriculture by smallholder farmers in Zimbabwe. Journal of Sustainable Development, 8(1), 69-82. https://doi.org/10.5539/jsd.v8n1p69

Pittelkow, C. M., Liang, X., Linquist, B. A., Groenigen, K. J., Lee, J., \& Lundy, M. E. (2015). Productivity limits and potentials of the principles of conservation agriculture. Nature, 517, 365-368. https://doi.org/10.1038/nature13809

Ryan, K., Gandha, T., Culbertson, M. J., \& Carlson C. (2014). Focus Group Evidence: Implications for Design and Analysis. American Journal of Evaluation, 35(3), 328-345. https://doi.org/10.1177/1098214013508300

Spielman, D. J. (2005). Innovation Systems Perspectives on Developing-Country Agriculture: A Critical Review. ISNAR Discussion Paper 2. Washington DC: IFPRI.

Spielman, J., \& Birner, R. (2008). How Innovative is Your Agriculture? Using Innovation Indicators and Benchmarks to Strengthen National Agricultural Innovation Systems. Washington: World Bank.

Steward, P. R., Dougill, A. J., Thierfelder, C., Pittelkow, C. M., Stringer, L. C., Kudzala, M., \& Shackleford, G. E. (2018). The adaptive capacity of maize-based conservation agriculture systems to climate stress in tropical and subtropical environments: A meta-regression of yields. Agriculture, Ecosystems and Environment, 251(1), 194-202. https://doi.org/10.1016/j.agee.2017.09.019

Tashakkori, A., \& Teddlie, C. (2010). SAGE Handbook of Mixed Methods in Social and Behavioural Research (2nd ed.). California: SAGE Publications. 
Thierfelder, C., Matemba-Musasa, R., Bunderson, T., Mutenje, M., Nyagumbo, I., \& Mupangwa, W. (2016). Evaluating manual conservation agriculture systems in southern Africa. Agriculture, Ecosystems and Environment, 222, 112-124. https://doi.org/10.1016/j.agee.2016.02.009

Thornton, P. K., Rosenstock, T., Förch, W., Lamanna, C., Bell, P., Henderson, B., \& Herrero M. (2018). A Qualitative Evaluation of CSA Options in Mixed Crop-Livestock Systems in Developing Countries. In L. Lipper, N. McCarthy, D. Zilberman, S. Asfaw, \& G. Branca (Eds.), Climate Smart Agriculture, Natural Resource Management and Policy 52 (pp. 385-423). Rome: FAO. https://doi.org/10.1007/978-3-319-61194-5_17

Waitt, G. (2010). Doing Foucaldian Discourse Analysis: Revealing Social Realities. In I. Hay (Ed.), Qualitative Research Methods in Human Geography (pp. 217-240). Oxford: Oxford University Press.

Wamsler, C. (2017). Stakeholder involvement in strategic adaptation planning: Transdisciplinarity and co-production at stake? Environmental Science and Policy, 75, 148-157. https://doi.org/10.1016/j.envsci.2017.03.016

Whitfield, S., Dougill, A., Dyer, J., Kalaba, F. Leventon, J., \& Stringer, L. (2015). Critical Reflection on Knowledge and Narratives of Conservation Agriculture in Zambia. Geoforum, 60, 133-142. https://doi.org/10.1016/j.geoforum.2015.01.016

Wood, B., Dougill, A., Quinn, C., \& Stringer, L. (2016). Exploring power and procedural justice within climate-compatible development project design: Whose priorities are being considered? Journal of Environment and Development, 25(4), 363-395. https://doi.org/10.1177/1070496516664179

World Bank. (2012). Agricultural Innovation Systems: An investment sourcebook. Washington DC: World Bank.

Young, O. R. (2002). The institutional dimensions of environmental change: Fit, interplay and scale. Cambridge, MA: The MIT Press.

\section{Note}

Note 1. A lead farmer is a self-motivated, experienced smallholder, able to impart his/her skills \& knowledge to follower (less progressive) farmers.

\section{Copyrights}

Copyright for this article is retained by the author(s), with first publication rights granted to the journal.

This is an open-access article distributed under the terms and conditions of the Creative Commons Attribution license (http://creativecommons.org/licenses/by/4.0/). 